\title{
PEMBIASAAN PERILAKU SENYUM, SALAM, SAPA DAN UCAPAN TERIMAKASIH PUSTAKAWAN TERHADAP PEMUSTAKA
}

\author{
Sahidi \\ Universitas Tanjungpura \\ e-mail: sahidiip@fkip.untan.ac.id \\ Musrifah \\ Universitas Tanjungpura \\ e-mail: musrifah26@yahoo.com
}

\begin{abstract}
Abstrak:
Tulisan ini bertujuan untuk mendeskripsikan pembiasaan perilaku senyum pustakawan terhadap pemustaka, pembiasaan perilaku salam dan sapa pustakawan terhadap pemustaka, dan pembiasaan ucapan terimakasih pustakawan terhadap pemustaka. Metode analisis masalah dalam tulisan ini menggunakan analisis deskriptif berdasarkan studi literatur dari berbagai sumber terkait dengan masalah dan tujuan. Adapun hasil dari pembahasan mengenai pembiasaan perilaku senyum bahwa senyum harus dimulai dan dipraktikan oleh pustakawan kepada pemustaka pada awal dimana pustakawan dan pemustaka bertemu. Bentuk senyuman yang dianjurkan untuk dilakukan oleh pustakawan terhadap pemustaka adalah senyum ketabahan/ketegaran dan senyuman tulus. Pembiasaan salam dan sapa dapat dipraktikan dan dibiasakan oleh pustakawan dengan menyapa pengunjung yang datang dengan ucapan "Assalamu 'alaikum warahmatullah" (bagi orang islam) atau "selamat pagi", "selamat siang", "selamat sore" maupun "selamat malam", dan berupa sapaan teguran. Sedangkan ucapan terimakasih pada umumnya merupakan bentuk ucapan akhir dari sebuah interaksi antara penyedia layanan dengan pengguna layanan. Pustakawan dapat mempraktikan dan membiasakan ucapan terimakasih kepada pemustaka seperti mengucapkan terima kasih atas kunjangan pemustaka, ucapan terima kasih atas pemanfaatan koleksi perpustakaan, ucapan terima kasih atas kepercayaan kepada pengguna dalam menggunakan layanan perpustakaan.
\end{abstract}

Kata Kunci: Senyum, Salam Sapa, Ucapan Terimakasih, Pustakawan

\begin{abstract}
:
This paper aims to describe the habituation of the librarian's smile behavior towards the user, the habituation of the librarian's greeting and greeting behavior towards the user, and the habituation of the librarian's gratitude towards the user. The method of problem analysis in this paper uses descriptive analysis based on literature studies from various sources related to the problem and goal. As for the results of the discussion about the habit of smiling behavior that smiling should be started and practiced by the librarian to the user at the beginning where the librarian and the user meet. The form of smile that is recommended for librarians to do to users is a smile of courage and a smile of sincerity. The custom of greeting and greeting can be practiced and accustomed to by the librarian by greeting visitors who come with the words "Assalamu 'alaikum warahmatullah" (for Muslims) or "good morning", "good afternoon", "good afternoon" or "good night", and in the form of a warning greeting. Meanwhile, gratitude is generally the final form of an interaction between service providers and service users. Librarians can practice and get used to gratitude to users such as saying thank you for the visitor's allowance, thank you for the use of library collections, thank you for trusting users in using library services.
\end{abstract}

Keywords: Smiles, Greetings, Thanks, Librarian

\section{Pendahuluan}

Manusia sebagai makhluk sosial tentunya saling berinteraksi antara satu dengan yang lainnya. Proses interaksi antara manusia yang satu dengan manusia lainnya disebut sebagai komunikasi. Komunikasi pertukaran gagasan, informasi, sikap, emosi, pendapat atau instraksi antara individu atau kelompok yang memiliki tujuan untuk membangun sesuatu, pemahaman dan mengkoordinasikan suatu aktivitas. ${ }^{1}$ Komunikasi merupakan suatu keniscayaan yang harus ada dalam konteks dunia pelayanan perpustakaan, sebab komunikasi dalam layanan perpustakaan merupakan penyatuan unsur-unsur yang ada yang saling 
membagun dalam memberikan keuntungan satu sama lain. Untuk itu, dibutuhkan interaksi sosial berupa komunikasi yang baik dalam membangun hubungan dengan pemustaka.

Pustakawan harus memiliki pengetahuan yang lebih tentang teknik bagaimana cara melayani pemustaka dengan baik, kemampuan berkomunikasi dengan baik kepada pemustaka, serta menjadi pustakawan yang menyenangkan yang dapat dijadikan "penolong" untuk mengatasi berbagai persoalan pemustaka terkait dengan kebutuhan informasi yang dibutuhkan, sehingga diharapkan semua pustakawan mampu memberikan layanan yang terbaik. Pelayanan yang diberikan kepada pengguna merupakan tulang punggung bagi keberlangsungan perpustakaan di masa yang akan datang. Pelayanan yang baik akan memberikan dampak pada loyalitas pengguna, sedangkan pelayanan yang buruk akan menjadikan pengguna tidak puas dan enggan kembali dan menggunakan kembali layanan perpustakaan. Untuk itu, perlunya memberikan pelayanan yang baik dengan membangun hubungan yang baik.

Hubungan antara pustakawan dan pemustaka dapat dibangun dengan komunikasi verbal dan non verbal. Komunikasi verbal yang dapat dibagun oleh pustakawan adalah mengucapkan salam, sapa, dan terimakasih, sedangkan komikasi non verbal adalah memberikan senyuman kepada pemustaka. Pemberian senyuman, salam, sapa, dan ucapan terimakasih merupakan komunikasi yang dianggap sederhana tetapi memiliki makna yang dalam. Namun banyak orang yang mengabaikan bentuk komunikasi seperti ini. Konsep senyum, salam, dan sapa sudah dibakukan oleh Dinas Tenaga Kerja dan Transmigrasi bersama pemerintah

\footnotetext{
${ }^{1}$ Priyanto Agus, Komunikasi dan Konseling: Aplikasi Dalam Sarana Pelayanan Kesehatan untuk Perawat dan Bidan. (Jakarta: Salemba Medika, 2009)

${ }^{2}$ Nakertrans jogja, (2012). Sosialisasi PES (Public Employment Services). http://www.nakertrans.jogjaprov.go.id/contentdetil. php?kat $=$ brta\&id $=$ Mjc $=\&$ fle. di akses pada tanggal 22 oktober 2020. pukul php?kat=br

${ }^{3}$ Hughes, Dewi: (2014). Duta Pendidikan Usia Dini http://kuoasbengkulu.com/perpustakaan-sepipenguniung-hughes-eoba-perhatikan-salesrokok/ diakses. tanggal 30/09/2020.pukul 13.09. WIB.
}

Jepang (JICA) dalam Public Employment Service (PES). ${ }^{2}$ Konsep senyum, salam, sapa ini menjadi penting karena penerapannya juga sudah sering dijumpai pada penerapan pelayanan publik seperti di hotel, bank, supermarket dan sebagainya. Senyum itu sendiri mengandung endorfim yang dapat membuat setiap orang merasa senang, bahagia, gembira ataupun suka terhadap sesuatu. Pada manusia terdapat $7 \%$ komunikasi verbal (kata-kata), $38 \%$ paralinguistik (nada, kecepatan, intonasi) dan sisanya sebanyak $55 \%$ adalah komunikasi non verbal (bahasa tubuh). Untuk itu, senyuman merupakan bahasa tubuh yang memiliki poin lebih dalam untuk menjalin komunikasi antar para pustakawan dan pemustaka. ${ }^{3}$

Pemberian layanan di perpustakaan masih sering memunculkan masalah terkait dengan komunikasi pustakawan yang dianggap kurang baik dan banyak yang berpendapat bahwa pandangan negatif tentang kualitas pustakawan dalam memberikan pelayanan terhadap pemustaka. Hal ini dapat dilihat dari indikator hubungan antara pustakawan dengan pemustaka terkait komunikasi pustakawan sendiri. Penilaian masyarakat terkait pelayanan perpustakaan bahwa pustakawan dalam memberikan pelayanan belum maksimal, belum menunjukan antusiasme tinggi, jarang tersenyum, tidak memberikan salam dan menyapa mengunjung perpustakaan, kurang merespon dan menaggapi kebutuhan pemustaka. Hal ini sangat berbeda dengan pelayanan jasa yang diberikan oleh karyawan perbankan yang sangat ramah, menebarkan senyuman, menyapa dengan ucapan salam, dan mengucapkan terimakasih kepada nasabahnya. Oleh karena itu, tidak heran jika perpustakaan sepi pengunjung dan kurang minat

\footnotetext{
${ }^{4}$ Hotomo. Kamus Lengkap Bahasa Indonesia.(Surabaya: Mitra Pelajar, 2005).

${ }^{5}$ Abu Muhammad Iqbal. Konsep Pemikiran Al-Ghazali Tentang Pendidikan. (Madiun: Jawa Timur, 2013).

${ }^{6}$ Djaali. Psikologi Pendidikan.(Jakarta: Bumi Aksara, 2013).

${ }^{7} \mathrm{M}$ Maswardi Amin. Pendidikan Karakter Anak Bangsa.(Yogyakarta: Hak Cipta, 2015)

${ }^{8}$ Gilang Dwi Prakoso. Mohammad Zainal Fatah. (2017). Analisis Pengar uh Sikap, Kontrol Perilaku, dan Norma Subjektif Terhadap Perilaku Safety (Analysis of Effect Attitude, Perceived, and Subjective Norm on Safety Behavior). Jurnal Promkes Vol. 5 No. 2 Desember 2017: 193 - 204.
} 
membaca dari masyarakat dan dianggap sebagai gudang dengan tumpukan buku yang menjenuhkan oleh sebagian masyarakat.

Masalah-masalah yang terjadi di atas merupakan sebuah tantangan yang harus diselesikan oleh perpustakaan dan pustakawan dengan meningkatkan kompetensi soft skill pustakawan dalam membangun hubungan yang baik dengan pemustaka agar perpustakaan terus memiliki citra positif di mata pemustaka dan juga sebagai upaya peningkatkan kegemaran membaca bagi masyarakat melalui perpustakaan.

Berdasarkan latar belakang permasalahan di atas, tujuan dari tulisan ini untuk mendeskripsikan:

1. Pembiasaan perilaku senyum Pustakawan terhadap Pemustaka

2. Pembiasaan perilaku salam dan sapa Pustakawan terhadap pemustaka

3. Pembiasaan ucapan terimakasih Pustakawan terhadap Pemustaka

\section{Tinjauan Pustaka Pembiasaan dan Perilaku}

Menurut Kamus Lengkap Bahasa Indonesia kata pembiasaan berasal dari kata biasa yang memiliki makna wajar perbuatan yang sering dilakukan dalam kegiatan sehari-hari. ${ }^{4}$ Kata pembiasaan berasal dari kata dasar biasa yang memperoleh imbuhan prefiks pe dan sufiks an, yang berarti proses membiasakan, yang pada akhirnya akan menghasilkan suatu kebiasaan. Pembiasaan merupakan suatu cara yang dilakukan untuk membiasakan seseorang bersikap adan bertindak sesuai dengan tuntunan agama ${ }^{5}$ Menurut Djaali pembiasaan adalah teknik bertindak yang melalui belajar secara berulang-ulang, yang pada akh-

9Gilang Dwi Prakoso. Mohammad Zainal Fatah. (2017). Analisis Pengaruh Sikap, Kontrol Perilaku, dan Norma Subjektif Terhadap Perilaku Safety (Analysis of Effect Attitude, Perceived, and Subjective Norm on Safety Behavior). Jurnal Promkes Vol. 5 No. 2 Desember 2017: 193 - 204

${ }^{10} \mathrm{https}: / / w w w . n a s e h a t q u r a n . c o m / 2019 / 02 /$ hadits-tentang-niat.html. Di akses pada tanggal 03 Oktober 2020. Pukul 08.03 WIB.

${ }^{11}$ Ayep Rosidi. (2017). Niat Menurut Hadis dan Implikasinya Terhadap Proses Pembelajaran. Jurnal Inspirasi - Vol. 1, No. 1, Januari - Juni 2017, $39-50$. irnya menjadi permanen. ${ }^{6}$ Menurut Amin ${ }^{7}$ indikator pembiasaan yaitu, pertama: Rutin, tujuannya untuk membiasakan seseorang melakukan sesuatu dengan baik. Kedua: Spontan, tujuannya untuk memberikan pendidikan secara spontan, terutama dalam membiasakan bersikap sopan santun dan terpuji terhadap sesama. Ketiga: Keteladanan, bertujuan untuk memberi contoh kepada orang lain atau kepada sesama.

Dalam kehidupan sehari-hari pembiasaan itu sangat penting, karena banyak orang yang berkuat atau bertingkah laku hanya karena kebiasaan semata. Kehidupan seseorang akan berjalan lambat sekali apabila tidak terbiasa dalam melakukan sesuatu, sebab sebelum melakukan sesuatu ia harus memikirkan terlebih dahulu apa yang akan dilakukan. Apabila seseorang telah terbiasa melakukan sesuatu hal yang baik, misalnya senyum, salam, sapa dan mengucapkan terimakasih maka ia tidak akan berpikir panjang lagi ketika ia melakukan hal tersebut. Sehingga jiwa seseorang atau kita dapat melaksanakan kebiasaan tersebut tanpa perlu bersusah payah, tanpa menemukan kesulitan, tanpa kehilangan banyak tenaga dan waktu. Berdasarkan hal ini, pustakawan ketika melayani pemustaka di perpustakaan perlu melakukan pembiasaan diri dalam penerapan soft skill pustakawan. Pembiasaan penerapan soft skill ini sebagai wujud dari komitmen mutu layanan perpustakaan menuju layanan yang berkualitas dalam mewujudkan kepuasan dan loyalitas pemustaka.

Seperti halnya dengan pustakawan yang tugasnya di perpustakaan adalah melayani pengguna dengan sepenuh hati, menghindari perilaku tercela yang dapat merusak reputasi diri dan instansi. Keberadaan sumber daya manusia merupakan

${ }^{12}$ Departemen Pendidikan Nasional. Kamus Besar Bahasa Indonesia ed ke-3. (Jakarta: Balai Pustaka, 2001).

${ }^{13}$ Abdurachman. Anatomi Senyum Kajian Kinesiologi. (Surabaya: Airlangga University Press Pusat Penerbitan dan Percetakan UNAIR, 2018)

${ }^{14} \mathrm{M}$. Ali Nurhasan Islamy. Penerapan Senyum Pustakawan Sebagai Keterampilan Sosial Di Perpustakaan. Jurnal: Berkala Ilmu Perpustakaan dan Informasl Volume XI Nomor 2, 2015, (30-48). 2011) 
salah satu sistem yang akan memperngaruhi kinerja lembaga perpustakaan yang nantinya akan memberikan efek juga pada kualitas pelayanan yang diberikan kepada penggunannya. Pengguna merupakan orang sang sangat potensial bagi eksistensi perpustakaan, perpustakaan ada karena adanya pengguna sehingga perlunya pustakawan menjaga bagaimana keberadaan pengguna yang potensial ini tetap bertahan di era perkembangan teknologi informasi yang sangat memudahkan orang untuk mendapatkan informasi dari mana saja. Untuk itu, menjaga sikap dan perilaku dalam pelayanan merupakan isu utama yang harus dijaga.

Izdihar ${ }^{8}$ mengungkapkan bahwa perubahan perilaku pada seseorang atau pada tenaga kerja merupakan suatu hal yang sangat sulit dirubah. Perilaku seseorang dipengaruhi oleh niat dari seseorang (tenaga kerja) itu sendiri, karena niat merupakan suatu pemikiran yang nyata dari refleksi rencana untuk menentukan perilaku pada seseorang tersebut. Untuk merubah atau mengetahui faktor apa yang dapat membuat perilaku seseorang maka di gunakan theory of planned behavior. Menurut Ajzen, ${ }^{9}$ Theory of Planned Behavior yaitu seseorang dapat melakukan sebuah perilaku apabila mempunyai niat, karena niat membuat seseorang melakukan suatu perilaku. Theory of planned behavior mempunyai beberapa faktor yang dapat mempengaruhi perubahan perilaku pada seseorang atau tenaga kerja, yaitu attitude, subjective norm, dan perceived.

Berbicara tentang niat, dalam sebuah hadist dikatakan yaitu sebagai berikut ${ }^{10}$ :

Artinya: dari Amirul Mukminin, Abu Hafs Umar bin Al Khattab radhiyallaahu 'anhu

\footnotetext{
${ }^{16}$ Muhammad Riza Febrianto, Herlina Siwi Widiana. Efek Pelayanan Senyum, Salam, Sapa Petugas Kasir Terhadap Kepuasan Konsumen Supermarket. Jurnal Psikologi Undip Vol.12 No.1 April 2013. hal 22-23.

${ }^{17}$ Abdurachman. Anatomi Senyum Kajian Kinesiologi. (Surabaya: Airlangga University Press Pusat Penerbitan dan Percetakan UNAIR, 2018).

${ }^{18}$ Abdurachman. Anatomi Senyum Kajian Kinesiologi. (Surabaya: Airlangga University Press Pusat Penerbitan dan Percetakan UNAIR, 2018)

${ }^{19}$ Sabri R. The Eight Components of a Balanced Smile. J Clin Orthodontics. vol 39, no 3, 2005, pp.155-167.
}

ta'ala, ia berkata: Saya mendengar Rasulullah shallallaahu 'alaihi wa 'alaa aalihi wasallam bersabda:"Sesungguhnya setiap perbuatan tergantung niatnya. Dan sesungguhnya setiap orang mendapat apa yang ia niatkan. Barang siapa yang hijrahnya karena Allah dan RasulNya, maka hijrahnya kepada Allah dan RasulNya. Dan barang siapa yang hijrahnya karena dunia yang ingin ia dapatkan atau karena wanita yang ingin ia nikahi maka hijrahnya pada apa yang ia niatkan."

Niat secara bahasa berarti al-qashdu adalah maksud atau tujuan. Imam al-Baidawi rahimhullah berkata: Niat merupakan keinginan hati terhadap sesuatu yang dirasa cocok untuk memperoleh manfaat dan menghindari resiko. Sedangkan secara syar'i niat ialah keinginan kuat untuk melaksanakan ibadah sebagai bentuk mendekatkan diri kepada Tuhan. Oleh sebab itu, agar proses pelayanan yang ada di perpustakaan bisa bernilai ibadah dan mendapatkan pahala, maka landasan niat yang ikhlas dan tulus ini sangatlah penting. Selanjutnya yang artinya "dan sesungguhnya setiap orang akan dibalas berdasarkan apa yang dia niatkan" mempunyai konsekuensi bahwa barangsiapa yang berniat akan sesuatu tertentu niscaya ia akan mendapatkan apa-apa yang ia niatkan dan setiap apa-apa yang ia tidak niatkan berarti ia tidak mendapatkannya. Hadits tersebut merupakan tolok ukur amal perbuatan hati atau batin seseorang. ${ }^{11}$

Hadis niat ini dapat dijadikan motivasi atau penyemangat bagi para pustakawan bahwa diperlukan niat yang dalam melakukan proses pembiasaan perilaku senyum, sapa, salam, dan mengucapkan terimakasih kepada pemustaka atau kepada pengunjung yang ia layani di per-

\footnotetext{
${ }^{20}$ Abdurachman. Anatomi Senyum Kajian Kinesiologi. (Surabaya: Airlangga University Press Pusat Penerbitan dan Percetakan UNAIR, 2018).

${ }^{21}$ Maktabah Syamila, Sunan Ibnu Majah (1395 juz 4 hal 299, 2008).

${ }^{22}$ M. Ali Nurhasan Islamy.(2015). Penerapan Senyum Pustakawan Sebagai Keterampilan Sosial Di Perpustakaan. Jurnal: Berkala Ilmu Perpustakaan Dan Informasl Volume XI Nomor 2.
} 
pustakan. Oleh karena itu pada diri seorang pustakawan maupun yang lainnya, hendaknya tajdidunniyat untuk melayani pemustaka dengan sebaik-baiknya, semata-mata karena Allah dan dengan tujuan tertentu sesuai dengan citacitanya.

\section{Senyum}

Menurut Kamus Besar Bahasa Indonesia pengertian senyum adalah gerak tawa ekpresif yang tidak bersuara untuk mengungkapkan rasa senang, gembira, suka dan sebagainya dengan mengembangkan bibir sedikit. ${ }^{12}$ Rahmadi, ${ }^{13}$ mengemukakan bahwa senyum merupakan proses penting bagaimana seseorang mampu menerima kehidupannya. Berawal dari senyum maka semua hal akan terasa ringan, sebab senyum dapat menstimuli seseorang berpikiran positif dan menghadirkan sikap yang lebih tulus dalam mengerjakan sesuatu. Kemampuan senyum juga terkait dengan kadar kematangan sesorang dalam menyikapi problema kehidupan. Ketidak mampuan seseorang menerima keadaan dan selalu berpikir negatif merupakan faktor penyebab susah tersenyum.

Adapun macam-macam senyum menurut $\mathrm{M}$. Ali Nurhasan Islamy ${ }^{14}$ yaitu sebagai berikut:

a. Senyum sinis

Senyum sinis merupakan cerminan senyuman ketidaksukaan kepada orang lain, faktor senyuman seperti ini karena rasa kecewa, iri dan dengki. Sebenarnya senyuman ini kurang menarik dilihat oleh mata, tetapi bagi orang yang memberi senyuman hal itu merupakan merupakan suatu bentuk ketidakpercayaan diri sendiri.

${ }^{23}$ McCraty, R., \& Childre, D. (2004). The gratefull heart: The psychophysiology of appreciation. In Emmons, R. A., \& McCullough, M. E. (Eds) The Psychology OF Gratitude. New York: Oxford University Press.

${ }^{24}$ Handrix Chris Haryanto, Fatchiah E. Kertamuda. Syukur Sebagai Sebuah Pemaknaan. Insight, Vol. 18 No. 2, Agustus 2016, 16-29

${ }^{25}$ Endang Danial. \& Warsiah Nanan. Metode Penulisan Karya Ilmiah. (Bandung: Laboraturium Pendidikan Kewarganegaraan, 2009).

${ }^{26}$ Sumarwan, U. Consumer behavior: Theory and its application in marketing. (Bogor: Ghalia Indonesia Publisher.,2004). b. Senyum menggoda

Senyum menggoda merupakan senyuman yang mampu membuat orang lain takluk dan tunduk. Jenis senyuman ini bisa diberikan sengaja maupun tidak sengaja. Hati-hati terhadap senyuman sejenis ini, mungkin saja si pemberi senyuman secara sengaja menggoda seseorang untuk melakukan maksud dan tujuan tertentu.

c. Senyum ketabahan/ketegaran

Senyum ketabahan/ketegaran adalah jenis senyuman yang menggambarkan ketabahan seseorang, dikala seseorang tersebut lagi berduka atau bersedih, si pemberi senyum ini dengan ikhlas memberikan senyuman terbaiknya. Jenis senyuman ini sulit diimplementasikan, karena membutuhkan tenaga dan kekuatan ekstra untuk menyunggingkan senyum di tengah kesedihan yang dialaminya.

d. Senyum tulus

Senyum tulus adalah senyuman yang diberikan seseorang kepada orang lain dengan tulus sepenuh hati, dengan tujuan membahagiakan orang lain. Hampir sama dengan senyum ketabahan atau ketegaran, namun jenis senyum ini tidak terbatas pada kondisi dan keadaan psikologis seseorang.

Menurut Liliweri ${ }^{15}$ senyuman dalam budaya Asia Tenggara umumnya berfungsi untuk menutupi kemarahan, perasaan malu, atau perasaan marah, sebagai alat untuk menyatakan terimakasih, permohohonan maaf atau makna secara tidak langsung menyatakan "ya". Senyum mengandung bermacam-macam arti dan pesan, dalam penelitian Ekman dan Friesen dalam Febrianto dan Widiana ${ }^{16}$ membagi jenis senyum menjadi dua yaitu:

a. Senyum yang dihayati (felt smiles)

Senyum yang dihayati ialah senyuman yang benar-benar dialami dan menunjukkan emosi positif. Senyum yang dihayati ini akan tampak apabila sudut bibir terangkat ke atas, 
sehingga tulang pipi terangkat dan terlihat dengan pipi yang terangkat, dan akan terlihat kerutan-kerutan disekitar mata.

b. Senyum palsu (false smile).

Senyum palsu ialah senyuman yang dibuat dengan sengaja untuk meyakinkan orang lain bahwa senyum yang diberikan berasal dari emosi positif. Pada senyum palsu sudut bibir membentuk senyum disertai dengan gerakangerakan otot wajah lain yang menunjukkan emosi negatif, misalnya mata yang terbelalak.

Abdurachman ${ }^{17}$ mengatakan bahwa senyum selain mencerminkan emosi seseorang, juga memiliki makna estetika yaitu unsur keindahan di dalamnya. Estetika dalam dunia medis meliputi kecantikan secara visual (tampak). Hal pertama kali ketika bertemu seseorang, tentu yang akan menjadi perhatian ialah wajahnya. karena wajah seseorang adalah sebagai identitas masing-masing individu. Ekspresi wajah seperti senyuman menjadi salah satu yang akan dilihat oleh setiap orang. Sehingga senyum yang indah menjadi salah satu aset seseorang.

Menurut Abdurachman ${ }^{18}$ komponen utama yang dapat dinilai untuk mendapatkan senyuman yang ideal yaitu sebagai berikut:

a. Garis bibir, digambarkan sebagai tinggi bibir atas terhadap gigi seri depan rahang atas. Garis bibir yang optimal ialah ketika bibir atas mencapai batas gusi, memperlihatkan keseluruhan panjang cervicoincisal dari gigi seri depan rahang atas bersama dengan gusi interproximal. Garis bibir yang tinggi memperlihatkan keseluruhan mahkota gigi ditambah jaringan gusi di atasnya, sedangkan garis bibir yang rendah memperlihatkan kurang dari $75 \%$ gigi depan rahang atas.

b. Lengkung senyum, merupakan hubungan antara kurva yang digambar sepanjang batas

${ }^{27}$ Haryono, B. How to win customer through customer service with heart. (Yogyakarta: ANDI, 2016).

${ }^{28}$ Maktabah Syamila. HR. Ibnu Hibban. 474, juz 2,2008, hal 221 gigi depan rahang atas dengan kontur bagian dalam bibir bawah pada pose senyum.

c. Kelengkungan bibir atas, bisa dilihat dari posisi tengah mulut hingga ke sudut mulut pada saat tersenyum. Lengkung ke atas apabila sudut mulut lebih tinggi dari posisi tengah mulut, lurus apabila sudut mulut dan posisi tengah mulut berada pada tinggi yang sama, dan lengkung ke bawah apabila sudut mulut lebih rendah dibandingkan posisi tengah mulut.

d. Lateral negative space, yaitu koridor bukal di antara gigi belakang dan sudut mulut saat tersenyum. Koridor bukal menggambarkan adanya bagian gelap saat tersenyum yang terbentuk di ujung mulut dengan permukaan bukal dari gigi rahang atas.

e. Kesimetrisan senyum, adalah posisi relatif dari sudut mulut terhadap bidang vertikal yang dapat diakses dengan memparalelkan sudut mulut dengan garis pupil.

f. Bidang oklusal depan, ditunjukkan dengan sebuah garis dari ujung gigi taring kanan hingga ujung gigi taring kiri.
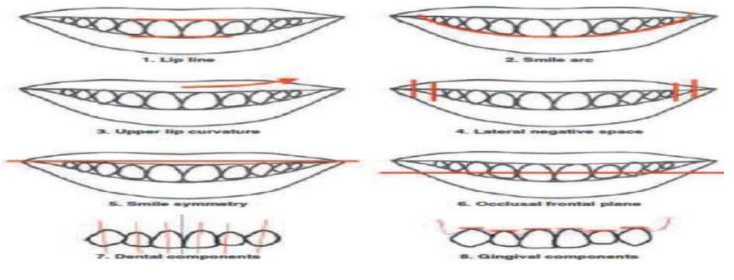

Gambar 1.

Delapan komponen utama dari senyum ideal (Sabri, 2005).

g. Gigi geligi, enam komponen senyum yang pertama menunjukkan hubungan antara gigi dan bibir dan bagaimana bibir dan jaringan lunak membentuk bingkai senyum. Senyum yang menyenangkan juga bergantung pada kualitas dan keindahan elemen gigi serta hubungan yang selaras di antara

\footnotetext{
${ }^{29}$ Ranchman Hermawan. Zulfikar Zen. Etika Kepustakawanan Suatu Pendekatan Terhadap Kode Etik Pustakawan Indonesia. (Jakarta: CV Sagung Seto, 2006)

${ }^{30}$ Endang Fatmawati. Mata baru penelitian perpustakaan: Dari servqual ke libqual: (Jakarta: Sagung Seto, 2013)
} 
gigi. Komponen gigi dari senyum meliputi ukuran gigi, bentuk gigi, warna, posisi, dan sudut (puncak) mahkota gigi, terhadap garis tengah dan keseimbangan lengkung senyum.

h. Gusi, komponen gusi yang perlu diperhatikan pada senyum adalah warna gusi, kontur gusi, tekstur, dan tinggi gusi. Peradangan gusi, papilla gusi yang tumpul, dan celah gusi yang terbuka serta batas gusi yang tidak rata membuat kualitas senyum menjadi buruk. ${ }^{19}$

Menurut Abdurachman, ${ }^{20}$ secara ilmiah senyum terbukti mempunyai beberapa manfaat, yaitu:

a. Meningkatkan sistem imunitas, yaitu dengan adanya kenaikan konsentrasi immunoglobulin A (IgA), IgG, IgM, dan leukosit.

b. Meningkatkan toleransi nyeri akibat peningkatan kadar hormon endorphin, hormon yang menghilangkan rasa nyeri.

c. Menurunkan kadar hormon stres seperti kortisol.

d. Meningkatkan ritme jantung dan saturasi oksigen.

e. Menghindarkan wajah dari kerutan karena aliran darah di sekitar wajah menjadi lebih lancar dan saraf secara konstan mengalami pergerakan sehingga otot wajah akan tetap kencang.

Berdasarkan hal tersebut bisa dikatakan manfaat tersenyum terhadap tubuh, yaitu bisa menjadikan tubuh rileks, senang dan bahagia. Efek yang timbul dari perasaan tersebut ialah menjadikan tubuh tidak mudah stress, lebih sehat, dapat membantu sistem kekebalan tubuh untuk bekerja lebih baik dan seimbang. Tersenyum juga bisa mengontrol banyak fungsi tubuh seperti makan, minum, tekanan darah, ritme jantung, siklus tidur dan dan emosional serta terhindar dari penyakit.

\section{Salam dan Sapa}

Salam dalam Islam merupakan ucapan yang terindah yang sering diucapkan sebagai bentuk rasa saying, cinta dan doa kita pada sesama. Menyebarkan salam juga termasuk kewajiban seorang muslim. Dengan mengucapkan salam antara muslim satu dengan yang lainnya akan menumbuhkan rasa cinta, bukan cinta biasa, namun cinta karena iman, cinta karena memiliki aqidah yang sama. Itulah indahnya salam. ternyata dengan kebiasaan mengucapkan salam, bisa menjadi sebab seseorang masuk ke dalam surga. sebagaimana dalam hadits Nabi shallallahu'alaihi wasallam bersabda yang artinya:

Berikanlah makan (kepada yang membutuhkan), tebarkanlah salam, maka engkau akan masuk surge dengan selamat, ${ }^{21}$

Salam dapat diberikan dengan cara mengucap "Assalamu 'alaikum warahmatullah" (bagi orang islam) atau "selamat pagi", "selamat siang", "selamat sore" maupun "selamat malam" pada saat bertemu dengan seseorang. Sementara sapaan termasuk teguran "selamat datang, apa kabar, lagi apa, dan sebagainya" pada awal pelayanan dan pengucapan "terimakasih" pada akhir pelayanan di perpustakaan.

Islamy, ${ }^{22}$ menyatakan bahwa sapa ialah suatu bentuk komunikasi awal seseorang dengan orang lain. Lebih komplit lagi ketika seseorang mengucapkan salam, sapaan dan sambil tersenyum, hal yang tampaknya sepele, namun kadang sulit dilakukan. Tidak sedikit seseorang mengabaikan betapa pentingnya hal tersebut. Apalagi hal tersebut diberikan oleh seseorang pimpinan kepada anak buahnya, tentu akan membuahkan rasa gembira, simpatik, dan bahkan juga kerja menjadi lebih semangat dan giat lagi. mengucapkan salam, sapa disertai senyuman itu tidak mahal dan tidak sulit, namun hal demikian, ternyata tidak semua orang bisa melakukannya. 


\section{Ucapan Terimakasih}

Ucapan terima kasih adalah ucapan yang sederhana, namun mempunyai arti yang sangat besar bagi kehidupan kita. Ucapan sederhana tersebut memiliki dampak positif terhadap lingkungan sosial. Mengucapkan terimakasih, kadang menjadi hal yang sulit untuk diungkapkan, apalagi ucapan tersebut tidak terbiasa dilakukan kepada orang lain. Ucapan sederhana yang mempunyai dampak luar biasa tersebut terkadang sering diabaikan oleh seseorang dalam hubungan sosial.

Mengucapkan kata terimakasih kepada orang lain berarti menghargai apa yang telah orang tesebut berikan kepada kita, dan sebagai rasa syukur kita kepada Allah atas apa yang diberikan-Nya. Dengan mengucapkan terimakasih kepada orang lain, maka orang tersebut merasa dihargai karena telah memberikan atau membantu. Mengucapkan terimakasih pada saat waktu yang tepat dapat menumbuhkan rasa bahagia dan mempererat hubungan secara berkelanjutan. Begitu juga dengan menjawab "ucapan terimakasih" tidak kalah pentingnya dengan mengucapkan "terimakasih" karena dengan menjawab ucapan terimakasih tersebut dari seseorang, maka orang itu juga akan merasa lebih dihargai, sebab telah mendapatkan respon yang baik dari orang yang berterimakasih tersebut. Ungkapan terimakasih bisa menimbulkan kesan/image yang baik bagi orang lain, sebab merasa dihargai maka orang tersebut akan melakukan lebih baik lagi di lain waktu. Mengucapkan terimakasih sama seperti halnya mengucap syukur kepada Allah yang telah memberikan kita nikmat. Hebatnya arti sebuah ucapan "terimakasih" membuat diri seseorang menjadi hati yang tulus tanpa pamrih, semakin banyak berterimakasih atau bersyukur, maka semakin banyak kebaikan yang didapatkan oleh seseorang tersebut. Sama halnya dengan bersyukur, semakin banyak seseorang mengucapkan rasa syukur, maka semakin banyak juga nikmat yang didapatkan oleh seseorang dari rasa skukur yang sudah diucapkan tersebut. McCraty, R., \& Childre, D ${ }^{23}$ lebih jauh mengatakan bahwa konsep syukur ini berasal dari kata "gratia" yang mempunyai makna menyukai atau kata "gratus" yang mempunyai makna menyenangkan.

Dalam konsep yang lain, gratitude diungkapkan sebagai bentuk perasaan yang dialami oleh seseorang ketika menerima suatu kebaikan atau keuntungan dari seorang penderma (Lambert, Graham \&Fincham, 2009). Emmons, McCullough and Tsang (2003) menjelaskan konsep syukur sebagai bentuk perasaan takjub, bangga, berterimakasih dan menghargai atas manfaat yang diperolehnya. Perasaan tersebut bisa diarahkan pada orang lain maupun pada diri sendiri. Selain halnya konsep yang sudah dijelaskan sebelumnya, konsep gratitude menurut McCullough,Tsangand Emmons (2004) sangat terkait dengan konsep kepribadian, emosi, kehidupan sosial dan kesejahteraan psikologis. Selanjutnya Fitzgerald (Emmons, 2004) menjelaskan bahwa dalam konsep gratitude terdiri dari tiga komponen yaitu berupa bentuk apresiasi yang hangat terhadap sesuatu, niat baik terhadap sesuatu dan keberadaan perilaku yang merupakan implikasi dari apresiasi dan niat tersebu. ${ }^{24}$

\section{Metode}

Jenis penelitian yang digunakan dalam tulisan ini adalah menggunakan studi literatur dengan analisis deskriptif terhadap setiap isu masalah. Menurut Danial dan Warsiah ${ }^{25}$ Studi literatur dilakukan oleh peneliti dengan cara mengumpulkan berbagai bahan bacaan seperti buku, artikel, dan majalah terkait dengan masalah dan tujuan penelitian. Penggunaan teknik ini bertujuan untuk mengungkap berbagai teori-teori yang relevan dengan permasalahan yang sedang dihadapi oleh peneliti sebagai rujukan dalam menganalisis penelitian. Sumber yang digunakan dalam tulisan ini merupakan sumber yang berkaitan mengenai tema pembiasaan perilaku senyum, salam, sapa, dan ucapan terimakasih. 


\section{Pembahasan}

\section{Senyum}

Menurut Sumarwan ${ }^{26}$ kualitas layanan secara umu terdiri atas lima aspek dimensi, yaitu aspek sarana fisik (tangibles), spek keandalan (reliability), spek responsifitas (responsiveness), aspek meyakinkan (assurance), dan aspek perhatian (empathy). Haryono ${ }^{27}$ berpendapat dari lima aspek dimensi tersebut yang paling mempengaruhi kualitas pelayanan adalah aspek dimensi tangibles. Aspek tangibles merupakan pelayanan dalam bentuk fisik yang di dalamnya terdapat penampilan karyawan (pakaian dan ekspresi ramah atau senyum).

Aspek tengibles seperti penampilan berpakain dan pemberian senyuman dapat dipraktikan oleh pustakawan kepada pemustaka pada awal dimana pustakawan dan pemustaka bertemu. Pustakawan mengawali interaksinya dengan memberikan senyuman kepada setiap pengunjung yang datang. Pemberian senyuman ini merupakan indikator bahwa pustakawan dalam melayani pengguna dengan ramah. Senyum merupakan tanda dimulainya sebuah ikatan yang secara tidak langsung telah terjalin adanya rasa ukhuwah. Dengan adanya senyum pada diri pustakawan akan menjadi karisma bagi seseorang tersebut. Serta dengan adanya senyum pada diri pustakawan akan menyembunyikan permasalahan pribadi pustakawan tersebut.

Senyuman merupakan bentuk dari profesionalitas diri dalam bekerja. Bentuk senyuman yang dianjurkan untuk dilakukan oleh pustakawan terhadap pemustaka adalah senyuman berikut ini:

\section{Senyum ketabahan/ketegaran}

Senyum ketabahan/ketegaran adalah jenis senyuman yang menggambarkan ketabahan seseorang pustakawan, dikala seorang pustakawan tersebut sedang berduka atau bersedih, pustakawan memberikan dengan ikhlas senyuman terbaiknya. Jenis senyuman ini sulit diaktualisasikan dalam kehidupan, karena membutuhkan kekuatan ekstra untuk menyunggingkan senyum di tengah kesedihan yang dialami pustakawan. Akan tetapi, demi tuntutan profesionalitas pustakawan, maka pustakawan harus melakukan senyuman ini untuk pemustaka.

\section{Senyum tulus}

Senyum tulus adalah senyuman yang diberikan seseorang pustakawa kepada orang lain dengan tulus sepenuh hati, dengan tujuan membahagiakan orang lain. Hampir sama dengan senyum ketabahan atau ketegaran, namun jenis senyum ini tidak terbatas pada kondisi dan keadaan psikologis seseorang. Dengan memberikan senyuman yang tulus kepada pemustaka baik yang mempunyai hubungan dengan kita maupun tidak mempunyai hubungan dengan kita, akan membuat hubungan tersebut terasa lebih akrab dan bahkan menambah keakraban dengan orang yang ada disekeliling kita.

Senyum dalam ajaran Islam bernilai ibadah. Seulas senyuman yang disunggingkan kepada seseorang setara dengan nilai sedekah, sebagaimana dalam sebuah hadits dikatakan ${ }^{28}$ :

Artinya: "Senyummu kepada saudaramu adalah shodaqoh"

Senyuman selain bernilai ibadah yang setara dengan nilai seekah, senyuman juga hal yang diperintahkan oleh Nabi Muhammad kepada ummatnya dalam berinteraksi sosial. Dalam sebuah hadis dikatakan yaitu:

Artinya: Janganlah kamu mengganggap remeh apa saja dari kebaikan, meski hanya engkau bertemu saudaramu dengan muka yang manis (senyum)

Menurut Hermawan dan Zen ${ }^{29}$, tugas pokok pustakawan adalah memberikan layanan perpustakaan dan informasi pada masyarakat pengguna (pemustaka). Untuk dapat memberikan pelayanan yang baik kepada pengguna, pustakawan harus mengembangkan sikap-sikap yaitu:

1. Mengenal masyarakat pengguna perpustakaan, baik dari segi usia, jenis kelamin, 
pekerjaan, pendidikan dan lain sebagainya.

2. Luwes dalam melayani, karena sikap luwes akan menumbuhkan keakraban.

3. Mengetahui kemauan penggunan, untuk itu pustakawan harus berkomunikasi dengan pemustaka. Sehingga dapat mengetahui apa yang diinginkan.

4. Mempromosikan produk layanan, bisa dilakukan dengan berbagai cara, antara lain melalui media cetak, seperti liflet, bosur, stikerm pamplet dan lain sebagainya.

5. Pemberian layanan hingga selesai, pustakawan harus mampu membentuk citra (image) positif, sehingga mereka akan puas terhadap apa yang telah mereka rasakan..

6. Tidak memaksakan kehendak, pustakawan dituntut untuk dapat memberikan keleluasan kepada masyarakat pengguna untuk memilih layanan sesuai dengan kebutuhan dan kenginannya.

7. Menjamin kerahasiaan dan privasi masyarakat pengguna adalah menjadi kewajiban pustakawan.

8. Mau mendengarkan keluhan, akan memberikan respek yang tinggi di hati pemustaka. Pemustaka akan merasa diberi perhatian, sehingga akan timbul sikap saling pengertian yang dapat meningkatkan citra baru perpustakaan.

9. Tidak berprasangka negatif, pustakawan harus selalu berpikir positif. Berpikir positif adalah sikap dasar yang harus dimiliki oleh pustakawan dalam melayani masyarakat pengguna.

10. Melayani dengan wajah ceria, dan senyum agar dapat menyenangkan masyarakat pengguna. Senyum bagi pustakawan hukumnya wajib dalam arti hilang senyuman berarti kehilangan respek dari publik kepadanya.

11. Mengucapkan terimakasih, mengucapkan terimakasih kelihatannya sepele, tetapi jika disampaikan dengan tulus, akan menjadi jurus yang ampuh untuk menaklukkan hati masyarakat pengguna. Perbuatan ini sering diabaikan, padahal pengaruhnya besar sekali.

\section{Salam dan Sapa}

Penerapan ucapan salam dan sapa merupakan upaya dalam merealisasikan kemampuan sosial pustakawan dalam memberikan layanan prima untuk mendukung kualitas perpustakaan. Menurut Fatmawati, ${ }^{30}$ bahwa kualitas layanan perpustakaan akan menjadi semakin baik apabila pustakawan mempunyai kemampuan sebagai perantara (intermediary) yang profesional bagi pemustakanya. Bagaimanapun, kemampuan, sikap dan penampilan pustakawan dalam melayani pemustaka sangat menentukan kualitas layanan perpustakaannya. Kemampuan sosial pustakawan dalam hal ini dapat diwujudkan misalnya menyapa pengunjung yang datang dengan ucapan "Assalamu "alaikum warahmatullah" (bagi orang islam) atau "selamat pagi", "selamat siang", "selamat sore" maupun "selamat malam", Apa yang bisa kami bantu Pak / Bu? pada saat bertemu dengan pengunjung perpustakaan. Sementara sapaan termasuk teguran "selamat datang, apa kabar, lagi apa, dan sebagainya" pada kegiatan awal pemberian layanan kepada penggunjung yang menggunakan layanan perpustakaan.

Pemberian sapaan kepada pemustaka tentunya perlu diperhatikan pemilihan kata-kata yang disukai dan cocok dengan pengunjung dan pemustaka. Pustakawan menyapa pengunjung dan pemustaka dengan nama yang baik, jika nama pengunjung dan pemustaka telah diketahui. Jika nama pemustaka belum ketahui, maka sebaiknya dipanggil dengan panggilan "Bapak, Ibu, atau Saudara". Pemilihan dan penggunaan kata ini disesuaikan dengan status pengunjung perpustakaan, usia pengunjung, dan jenis kelamin pengunjung yang datang. Apabula pengunjung atau pemustaka usianya lebih tua atau status sosialnya lebih tinngi, maka dapat menyapa dengan sapaan "Bapak atau Ibu", jika usianya setara dengan pustakawan atau diperkirakan statusnya sama atau sederajat, dapat menggunakan sapaan "Saudara/Saudari". 
Kegiatan memberi salam dan menyapa merupakan upaya dalam memberikan kepuasan dan loyalitas pemustaka. Menyapa pemustaka merupakan reaksi atau sikap tanggap terhadap keberadaan dan kebutuhan pemustaka pada menggunakan layanan perpustakaan. Pemustaka dipastikan membutuhkan berbagai informasi penting terkait apa yang dibutuhkan dengan cepat serta perhatian khusus dan empati dari pustakawan dalam melayani. Saat pustakawan melihat pemustaka yang sedang kebingungan, maka sikap pustakawan adalah menghampiri dan menyapa pemustaka dengan menawarkan bantuan. Ini merupakan sikap yang dilakukan pustakawan yang professional yang nantinya akan berimplikasi pada peningkatan pengunjung perpustakaan.

\section{Ucapan Terimakasih}

Ucapkan "terima kasih" kepada pemustaka pada umumnya digunakan untuk mengahiri pembicaraan. Misalnya: Terima kasih atas kunjangan Bapak / Ibu di Perpustakaan Kami, terima kasih atas pemanfaatan koleksi perpustakaan Kami, terima kasih Bapak telah memilih perpustakaan Kami, terima kasih atas kepercayaan Bapak / Ibu menggunakan layanan yang telah kami sediakan, dan lainnya. Kata terima kasih termasuk salah satu ungkapan yang disukai penggunan perpustakaan, karena ungkapan terimakasih merupakan bentuk penghargaan yang diberikan oleh penyedia layanan kepada pengguna layanan. Perpustakaan sebagai lembaga non profit oriented harus mengedepankan kepuasan pelanggan dalam memberikan layanan. Untuk itu, perlunya sikap demikian sebagai ujung tobak keberhasilan lembaga perpustakaan.

Ungkapan terimakasih pustakawan terhadap pemustaka karena telah berkunjung ke perpustakaan atau sebaliknya dapat memberikan manfaat, yaitu sebagai berikut:

1. Ucapan terimakasih bisa membuat hati pemustaka bahagia karena ucapan terimakasih merupakan kata yang paling indah dan me- narik didengar oleh pemustaka

2. Ucapan terimakasih bisa menghindari atau mengurangi stress pemustaka

3. Ucapan terimakasih bisa membuat diri seseorang tetap menjadi sehat

4. Ucapan terimakasih bisa meningkatkan kepercayaan diri

5. Ucapan terimakasih bisa menghargai orang lain

6. Ucapan terimakasih bisa mempererat hubungan dengan pemustaka

7. Ucapan terimakasih bisa membuat seseorang merasa lebih empati kepada sesama

8. Ucapan terimakasih bisa memotivasi seseorang untuk berbuat yang lebih baik dan positif

\section{Kesimpulan dan Saran}

Perpustakaan harus menjaga kualitas layanan khususnya kualitas layanan pada aspek tangibles dalam bentuk pemberian layanan fisik yang di dalamnya terdapat penampilan pustakawan berupa pemberian senyum, salam dan sapa, serta ucapan terimakasih. Senyum merupakan aspek tengibles yang harus dipraktikan oleh pustakawan kepada pemustaka pada awal dimana pustakawan dan pemustaka bertemu. Senyuman merupakan bentuk dari profesionalitas diri pustakawan dalam bekerja. Bentuk senyuman yang dianjurkan untuk dilakukan oleh pustakawan terhadap pemustaka adalah senyum ketabahan/ketegaran dan Senyuman tulus.

Salam dan sapa merupakan aspek fisik dalam kualitas perpustakaan yang perlu dipraktikan dan dibiasakan oleh pustakawan dalam menjalankan tugasnya secara professional. Salam dan sapa dapat dipraktikan dan dibiasakan oleh pustakawan dengan menyapa pengunjung yang datang dengan ucapan "Assalamu 'alaikum warahmatullah" (bagi orang islam) atau "selamat pagi", "selamat siang", "selamat sore" maupun "selamat malam", dan berupa sapaan teguran dengan pertimbangan pemilihan kata yang cocok dengan pemus- 
taka yang dihadapi pustakawan. Sedangkan ucapan terimakasih pada umumnya merupakan bentuk ucapan akhir dari sebuah interaksi antara penyedia layanan dengan pengguna layanan. Pustakawan dapat mempraktikan dan membiasakan ucapan terimakasih kepada pemustaka seperti mengucapkan terima kasih atas kunjangan pemustaka, ucapan terima kasih atas pemanfaatan koleksi perpustakaan, ucapan terima kasih atas kepercayaan kepada pengguna dalam menggunakan layanan perpustakaan, dan ucapan terimakasih lainnya.

Pembiasaan perilaku senyum, salam, sapa dan ucapan terimakasih merupakan suatu bentuk mempertahankan dan meningkatkan kualitas layanan yang ada di perpustakaan. Untuk itu, pembiasaan perilaku senyum, salam, sapa, dan ucapan terimakasih harus menjadi soft skill khusus bagi pustakawan dalam memberikan layanan prima kepada pemustaka dan jika perlu untuk ditingkatkan soft skill ini, maka perlu diadakan pelatihan-pelatihan agar perilaku ini menjadi kebiasaan dalam sebuah pelayanan perpustakaan.

\section{Referensi}

Agus, Priyanto. (2009). Komunikasi dan Konseling: Aplikasi Dalam Sarana Pelayanan Kesehatan untuk Perawat dan Bidan. Jakarta: Salemba Medika.

Abdurachman. (2018). Anatomi Senyum Kajian Kinesiologi. Surabaya: Airlangga University Press Pusat Penerbitan dan Percetakan UNAIR.

Amin, M Maswardi. (2015). Pendidikan Karakter Anak Bangsa.Yogyakarta: Hak Cipta.

Danial, Endang \& Nanan, Warsiah. (2009). Metode Penulisan Karya Ilmiah. Bandung: Laboratorium Pendidikan Kewarganegaraan.

Djaali. (2013). Psikologi Pendidikan.Jakarta: Bumi Aksara.

Departemen Pendidikan Nasional. (2001). Kamus Besar Bahasa Indonesia ed. ke-3. Ja- karta, Balai Pustaka.

Fatmawati, Endang. (2013). Mata baru penelitian perpustakaan: Dari servqual ke libqual: Jakarta: Sagung Seto.

Gilang Dwi Prakoso. Mohammad Zainal Fatah. (2017). Analisis Pengaruh Sikap, Kontrol Perilaku, dan Norma Subjektif Terhadap Perilaku Safety (Analysis of Effect Attitude, Perceived, and Subjective Norm on Safety Behavior). Jurnal Promkes Vol. 5 No. 2 Desember 2017: 193 - 204.

Hermawan, Rahcman, Zulfikar Zen. (2006). Etika Kepustakawanan Suatu Pendekatan Terhadap Kode Etik Pustakawan Indonesia. Jakarta: CV Sagung Seto.

Haryanto, Handrix Chris, Fatchiah E. K. (2016). Syukur Sebagai Sebuah Pemaknaan. Insight, Vol. 18 No. 2, Agustus 2016.

Hughes, Dewi. (2014). Duta Pendidikan Usia Dini http://kuoasbengkulu.com/perpustakaansepipenguniung-hughes-eoba-perhatikansalesrokok/diakses. tanggal 30/09/2020.pukul 13.09. WIB.

Iqbal, Abu Muhammad (2013). Konsep Pemikiran Al-Ghazali Tentang Pendidikan. Madiun: Jawa Timur.

Islamy, M. Ali Nurhasan (2015). Penerapan Senyum Pustakawan Sebagai Keterampilan Sosial Di Perpustakaan. Jurnal: Berkala Ilmu Perpustakaan dan Informasl Volume XI Nomor 2.

Haryono, B. (2016). How to win customer through customer service with heart. Yogyakarta: ANDI.

Liliweri, A. (2011). Komunikasi: Serba ada serba makna. Jakarta: Kencana

Muhammad Riza Febrianto, Herlina Siwi Widiana. (2013). Efek Pelayanan Senyum, Salam, Sapa Petugas Kasir Terhadap Kepuasan Konsumen Supermarket. Jurnal Psikologi Undip Vol.12 No.1 April 2013. hal 22-23.

Maktabah Syamila. (2008). HR. Ibnu Hibban 474, juz 2, hal 221. 
McCraty, R., \& Childre, D. (2004). The gratefull heart: The psychophysiology of appreciation. In Emmons, R. A., \& McCullough, M. E. (Eds) The Psychology OF Gratitude. New York: Oxford University Press.

Nakertrans jogja, (2012). Sosialisasi PES (Public Employment Services). http://www. nakertrans.jogjaprov.go.id/contentdetil. php?kat $=$ brta\&id $=\mathrm{Mjc}=\&$ fle. di akses pada tanggal 22 oktober 2020. pukul 20:03 WIB.

Ratminto dan Winarsih. (2008). Manajemen Pelayanan: Pengembangan Model Konseptual, Penetapan Citizen's Charter dan Standar Pelayanan Minimal. Yogyakarta: Pustaka Pelajar.

Rosidi, Ayep. (2017). Niat Menurut Hadis dan
Implikasinya Terhadap Proses Pembelajaran. Jurnal Inspirasi - Vol. 1, No. 1, Januari - Juni 2017, 39-50.

Rizkala., Adam. Penjelasan Hadits Tentang Niat dan Faedahnya - Hadits Arbain ke 1. Dalam https://www.nasehatquran.com/2019/02/hadits-tentang-niat.html. Di akses pada tanggal 03 Oktober 2020. Pukul 08.03 WIB.

Sabri R. (2005). The Eight Components of a Balanced Smile. J Clin Orthodontics. vol 39, no 3, pp.155-167.

Sumarwan, U. (2004). Consumer behavior: Theory and its application in marketing. Bogor: Ghalia Indonesia Publisher. 